\title{
editorial
}

\section{Adherencia al tratamiento}

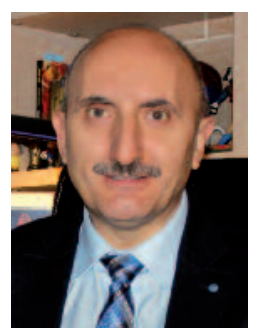

Alipio Gutiérrez Sánchez Presidente de la Asociación Nacional de Informadores de la Salud (ANIS). Director de informativos de Telemadrid.
Según datos del Observatorio de Adherencia al Tratamiento (OAT), en atención primaria, el $57 \%$ de los pacientes no cumplen con sus tratamientos y son las personas polimedicadas las que menos lo hacen. La falta de accesibilidad, el mal uso, los olvidos o la poca información que reciben son algunos de los obstáculos que los pacientes encuentran en su día a día. Sin duda, estamos ante un problema de primera magnitud en los países desarrollados, porque hablamos de pautas de salud incumplidas que no solo aumentan el riesgo de comprometer la salud de las personas, sino que suponen un gasto económico de primer nivel, al tiempo que un desperdicio imperdonable. Según datos facilitados por el Instituto Nacional de Estadística (INE), en 10 años, uno de cada cinco españoles será mayor de 65 años y el coste sanitario por persona aumentará entre 4 y 12 veces con respecto al actual.

Es fácil pensar que aquellos ciudadanos afectados por varias enfermedades crónicas, que viven con el dedo permanentemente puesto sobre el pulso de la muñeca, acaben olvidándose de su situación de enfermedad y abandonen la medicación a poco que mejoren los síntomas, si no de todas, de algunas de sus enfermedades. Es fácil también pensar que pueda deberse a olvidos rutinarios, que hacen que las dosis de los fármacos se tomen un poco al albur de cada uno, saltándose tomas, pero manteniendo, más o menos, las pautas prescritas por el médico. También es fácil pensar que sean las personas mayores quienes más incumplen los tratamientos farmacológicos cuando, si analizamos estudios como el del OAT, la situación es bien distinta. Los resultados reflejan que, con el aumento de la edad del paciente, aumenta también el cumplimiento de la pauta prescrita por el médico: entre los 61 y los 70 años, los pacientes registran una adherencia del $53 \%$, cifra que aumenta hasta el $61 \%$ entre los 81 y los 90 años de edad.

Mejorar estos datos debe pasar, según opinan diversos expertos, por una reorganización de la atención sanitaria hacia un modelo que integre los niveles asistenciales y que potencie la relación de los profesionales de la salud con sus pacientes y su entorno. Ahora toca trabajar en ello. Pero no solo en la mejora, también en la evaluación de las consecuencias y en las herramientas que faciliten los datos. Sin embargo, esa evaluación no sirve si se realiza en una u otra comunidad autónoma de forma aislada. Conviene que, sobre este asunto tan determinante para la salud de las personas, se apueste por un programa común, que sirva para todo el Estado, por lo que parecería conveniente su abordaje desde instancias como el Consejo Interterritorial de Salud. ¿Será posible? Yo soy muy escéptico respecto a ese organismo, 
que apenas sirve para nada. Así las cosas, deberíamos prestar especial atención a las acciones individuales, tanto de los profesionales sanitarios, médicos, enfermeras y farmacéuticos, como de las profesiones mencionadas. La educación es vital no solo para pacientes, también para los profesionales. Utilizar un lenguaje sencillo y fomentar la participación del paciente son las claves para recuperar la confianza perdida en la relación médico-paciente. El pilar es empoderar al enfermo como eje del sistema, pero, para ello, los profesionales tienen que ir más allá de la propia enfermedad y tener en cuenta otros aspectos, como los psicológicos o los sociales, y algo capital, que, por desgracia, apenas conocen estos profesionales: las habilidades de comunicación en la consulta. Saber manejar el lenguaje no verbal para identificar lo que el paciente quiere contar o no se atreve a hacerlo, saber utilizar las técnicas de persuasión para trasladar a los pacientes que el cumplimiento terapéutico va más allá de tomar una pastilla a una hora del día, es algo que cada individuo puede hacer para conseguir una mayor calidad de vida y mejorar los pronósticos de la enfermedad a medio y largo plazo, pero siempre es algo que exige su propio compromiso de actuar. Y después está la fidelización del profesional sanitario; es decir, qué hacen los médicos especialmente para conseguir que su paciente vuelva a confiar en ellos y acuda a las citas o revisiones establecidas. Cualquier cambio en la actitud de los pacientes debería hacernos sospechar y, aún más, si el paciente decide cambiar de médico. Ese es un síntoma que conviene no olvidar. Seguramente muchos piensen -y no les faltará razón- que eso ocurre siempre, porque siempre hay gente descontenta. De acuerdo, pero no deja de ser un síntoma para preguntarnos por qué ha ocurrido. En las relaciones de confianza, como la que se establece entre médico y paciente, quien desempeña el papel de actor principal, quien ejerce habitualmente de emisor del mensaje (el médico) debe pensar que, si hay algún problema en la comuni- cación, la culpa no siempre la tiene el otro, el receptor, el paciente. En comunicación, cuando existe un problema, es el emisor quien debe siempre preguntarse qué ha ocurrido para que algo suceda; qué puede hacer mejor para evitar malos entendidos o confusiones. Siempre es «culpa»del emisor. Si pensamos así, será más fácil que aprendamos a comunicar con mayor empatía, favoreciendo el diálogo, el compromiso y, a la postre, el cumplimiento fiel del paciente de las pautas terapéuticas establecidas. Y ¿cuáles son las claves de la fidelización del paciente? La primera es la competencia profesional; la segunda, el carácter, el carisma; la tercera, la compostura; la cuarta, la empatía, ponerte en el lugar del otro, y finalmente, la sociabilidad. Todas ellas juntas nos hacen ser más creíbles y, en la credibilidad, está el éxito de cualquier empresa y de cualquier persona. Solo nos tendrán en cuenta si somos capaces de transmitir credibilidad, que no consiste solo en disponer de conocimiento científico: es algo más.

Por supuesto que hay herramientas que nos van a facilitar a todos esa credibilidad. Me refiero, por ejemplo, a las nuevas herramientas tecnológicas de comunicación en el ámbito sanitario, como la receta electrónica y las aplicaciones para móviles y tabletas que disponen de alertas para que el cumplimiento terapéutico sea más fiel a lo establecido y evitar los olvidos.

Los datos del OAT confirman que una mayoría de la población (56\%) desearía tener más información sobre su enfermedad y tratamientos, principalmente, las personas más jóvenes y con un mayor nivel de estudios. En este punto, todos los profesionales de la salud que interactúan con los pacientes tienen el papel fundamental de proporcionarles información clara, concisa y segura que mejore su calidad de vida. Conviene, pues, transmitir la idea de que la buena praxis no es suficiente para la satisfacción del paciente y que, en la gran mayoría de los casos, es la comunicación la que genera la confianza y la fidelización. 